\title{
The Profitability of Public Enterprises in Pakistan
}

\section{KHWAJA SARMAD*}

The importance of the profitability of public enterprise for capital expansion and development has been highlighted in various studies, e.g. in [2], [4] and [5]. In Pakistan the increasing role of the public sector in resource mobilization points to the need for analysing public enterprise profitability because of its immense importance for capital financing and growth.

This paper analyses the profitability of public enterprises in Pakistan using a ratio analysis methodology which chooses performance indicators on the basis of their sensitivity to the operational health of the enterprises. The profitability ratios discussed here have been derived from the public-enterprise balance-sheets [9] and constitute the choice-set from which four ratios have been selected on the basis of their predictive power. (See [1], [3], [8] and [10].) In this way, the arbitrariness involved in the choice of the appropriate ratios for analysing enterprise profitability is overcome, even though profitability measurement may still be distorted to such an extent that effective prices diverge from opportunity costs. This makes the task of performance evaluation difficult as such an exercise has to take into account the implications of market distortions. The usefulness of profitability as an indicator of relative inter-firm performance is therefore limited by the fact that prices are administered with reference to products and are not tied to firm experience. But, owing to the lack of data on the required variables, the effect of market distortions on profitability is difficult to analyse.

To assess developmental implications of profitability, gross profit and factor productivity of low-performing enterprises have been compared with those of highperforming enterprises. The comparison should provide useful insights into the operational performance of public enterprises.

\section{Ratio Analysis}

The methodology used for selecting appropriate profitability-performance indicators is a simpler version of the one developed by Gupta in [3]. The seventeen 
ratios specified on the basis of studies by Ahmed [1], Gupta [3], Mohsin [8] and Walker and Baughn [10], constitute the choice-set from which four have been selected on the basis of their predictive power, which is determined by the number of enterprises accurately classified by a ratio between two equal groups of known wellperforming and poorly performing enterprises (Appendix Table 1). Two ratios with equally low classification errors were ignored because they measure gross profit after depreciation, while in public enterprises depreciation can be considered a part of profit since it does not involve a cash expense and can be used for investment purposes [8]. The break-even points, which minimize the number of misclassifications in the rank ordered arrays, are also used to identify the badly performing enterprises which are listed in Table 1. (Also see Appendix Tables 1 and 2).

Table 1

Low-Performing Enterprises in 1981-82

\begin{tabular}{cll}
\hline & Classification & Enterprise Code \\
\hline I. & Classified by all four Ratios & $1 ; 12 ; 24 ; 25$ \\
II. & Classified by three Ratios & $5 ; 22 ; 26 ; 40 ; 41$ \\
\hline
\end{tabular}

Source: Appendix I, Table 2.

\section{Performance Comparison}

The analysis of the profitability levels of poorly performing enterprises (as measured by the four selected ratios) and their relative performances from 1977-78 to $1981-82$ showed that the poor performance during the final year of this period was the result of the aggravation of a declining trend which was already present in the earlier years of the period. The typical path of a poorly performing enterprise during this period was characterized by a substantial annual decline in profitability.

Table 2 compares gross profit per employee, the value added per employee, gross profit as a percentage of the value added, and labour share in the value added for poorly performing and high-performing enterprises, and points to certain conclusions regarding the effect of operational conditions on enterprise profitability.

The table shows that poorly performing enterprises were characterized by large deficits per employee, and the figures for gross profit as a percentage of the value added exhibited wide fluctuations. However, even when the deficits were extremely large, as in the case of the enterprise bearing Code Number 24, the enterprises have not been allowed to go into liquidation, with the balance required for day-today operation being subsidized from government revenues. The value added per employee was also much smaller in the poorly performing enterprises, pointing to a relatively unproductive utilization of labour. That labour share in the value added by the poorly performing enterprises is greater than that in the high-performing enterprises shows, assuming similar wage levels in the two categories of enterprises, much higher labour intensities in the low-performing enterprises.

Table 2

Gross Profit, ${ }^{1}$ Factor Productivity and Utilization (1981-82)

\begin{tabular}{ccccc}
\hline $\begin{array}{c}\text { Enterprise } \\
\text { Code }\end{array}$ & $\begin{array}{c}\text { Gross Profit } \\
\text { per Employee } \\
\text { (Thousand Rs.) }\end{array}$ & $\begin{array}{c}\text { Value Added } \\
\text { per Employee } \\
\text { (Thousand Rs.) }\end{array}$ & $\begin{array}{c}\text { Gross Profit } \\
\text { as Percentage of } \\
\text { Value Added }\end{array}$ & $\begin{array}{c}\text { Labour Share } \\
\text { in Value Added } \\
\text { (Percent) }\end{array}$ \\
\hline $\begin{array}{c}\text { Low-performing Enterprises } \\
\text { ( }\end{array}$ & & & & \\
1 & -6.12 & 18.43 & -33.20 & 69.86 \\
5 & -10.42 & 6.08 & -171.50 & 361.29 \\
12 & -52.73 & 48.46 & -108.80 & 70.11 \\
22 & 0.33 & 17.28 & 1.90 & 85.50 \\
24 & -364.91 & 9.01 & -405.20 & 291.72 \\
25 & 8.29 & 16.14 & -51.30 & 95.58 \\
26 & 4.95 & 8.68 & 57.10 & 192.36 \\
40 & -55.04 & 1.47 & -373.00 & 1113.04 \\
41 & -12.56 & 2.48 & -506.80 & 283.76 \\
High-performing & Enterprises ${ }^{3}$ & & & \\
11 & 31.40 & 51.10 & 61.50 & 75.11 \\
14 & 24.80 & 24.05 & 103.10 & 68.93 \\
15 & 95.66 & 144.10 & 66.40 & 22.74 \\
23 & 14.80 & 35.29 & 41.90 & 58.46 \\
35 & 59.80 & 90.31 & 66.20 & 30.13 \\
38 & 129.04 & 776.90 & 16.60 & 3.99 \\
39 & 51.62 & 81.45 & 63.40 & 29.03 \\
42 & 91.00 & 372.35 & 24.40 & 35.97 \\
\hline
\end{tabular}

Source: Calculated from [9].

Notes: ${ }^{1}$ Gross Profit is measured after deducting financial charges and depreciation. ${ }^{2}$ Identified in Table 1.

${ }^{3}$ The healthy enterprises chosen are those which have been rated among the top 15 enterprises by at least three selected ratios. 


\section{Determinants of Enterprise Profitability}

Table 3, which reports the variation of profit rate by enterprise size, shows a substantial difference between various asset groups, with the smaller group having profit rates higher than the overall average. But the greater standard deviation for this group shows much wider intra-group diversity of profit rate. However, when the poorly performing enterprises are excluded, the inverse relation between the rate of profit and asset size becomes even more clear. The standard deviation is also much lower, showing that the large variation was due to the presence of the poorly performing enterprises, which have a very low rate of profit.

The lower profit rate in bigger enterprises can be due to two reasons. First, such enterprises have a large share of the total supply of the product and because of less competition have little incentive to improve efficiency. Secondly, given the limited size of the domestic market, capacity utilization in large enterprises is low, particularly during the earlier years of operation. For enterprises 1 and 2, which suffered from chronic under-utilization of capacity, this was quite true. For the other large-sized enterprises, the problems were more specific and largely of a transitional nature; e.g. enterprises code-numbered 36,37 and 38 accumulated huge inventories because of low fertilizer off-take and also suffered from curtailment of gas supplies, which adversely affected production as well as equipment.

Table 3

Enterprise Size and Rate of Profit

\begin{tabular}{lccccc}
\hline \multirow{2}{*}{$\begin{array}{c}\text { Asset-Size } \\
\text { Group }\end{array}$} & \multicolumn{2}{c}{ All Enterprises } & & \multicolumn{2}{c}{ All Enterprises Excluding Slack } \\
\cline { 2 - 3 } \cline { 6 - 6 } (Million Rupees) & $\begin{array}{c}\text { Number of } \\
\text { Enterprises }\end{array}$ & $\begin{array}{c}\text { Rate of Profit } \\
\text { (Percent) }\end{array}$ & & $\begin{array}{c}\text { Number of } \\
\text { Enterprises }\end{array}$ & $\begin{array}{c}\text { Rate of Profit } \\
\text { (Percent) }\end{array}$ \\
\hline Above 750 & 6 & $7.69(5.49)$ & 5 & $9.05(5.01)$ \\
500 to 749 & 6 & $10.14(2.65)$ & 6 & $10.14(2.65)$ \\
200 to 499 & 12 & $9.82(4.91)$ & & 11 & $10.69(4.35)$ \\
100 to 199 & 9 & $14.58(7.35)$ & & 9 & $14.38(7.35)$ \\
Below 100 & 21 & $13.33(14.07)$ & 14 & $20.12(12.10)$ \\
All Enterprises & 54 & $\mathbf{1 1 . 7 8 ( 1 0 . 0 3 )}$ & $\mathbf{4 5}$ & $\mathbf{1 4 . 1 2 ( 9 . 1 6 )}$ \\
\hline
\end{tabular}

Source: Calculated from [9].

Notes: 1. Figures in brackets are standard deviations.

2. Rate of profit is measured by $\mathrm{PRGP}_{3}$.
It is interesting to note that while the inverse relation between enterprise size and rate of profit is true in general, the incidence of slackness is mostly in the small asset-size group. Seven of the total of nine poorly performing enterprises belonged to the smallest asset-size group, which had the highest rate of profit among various groups.

The determinants of public enterprise profit rate have been investigated with the help of two profitability ratios, viz. $\mathrm{PRGP}_{3}$ and $\mathrm{PRGP}_{4}$. Following Lindsey [7], the logarithm of enterprise assets has been used to capture the effect of enterprise size on profit rate and the growth of assets (during the period from 1977.78 to 1981-82) to account for the profit variation due to supply or demand factors. Leverage has been included to test the effect of the equity-asset ratio on the rate of profit.

The regression results are reported in Table 4. For all enterprises, the explanatory power of the regression is slightly less for PRGP $_{3}$ ( 16.3 percent) than for PRGP $_{4}$ (18.9 percent), which shows that gross profit, measured after taking into account depreciation and financial charges and expressed as a percentage of total assets and accumulated depreciation, is more appropriate as a measure of the profit rate. This observation also holds true for the different sub-groups of enterprises.

The explanatory power is raised substantially when separate equations are estimated for different size groups of enterprises, suggesting that the low value of $\mathrm{R}^{2}$ for all enterprises was partly due to the different behaviour of large and small enterprises.

A negative relation is found between the enterprise size and rate of profit for all enterprises and for large ones as well. The reasons for this have been explained earlier in the paper. However, within the group of small enterprises a positive relationship is found, which points to the existence of a certain critical level beyond which enterprise size begins to exert a negative influence on the profit rate. The sign for the growth rate of the variable for assets is positive and highly significant for all groups. This is explained partly by the fact that during the period from 1977-78 to $1981-82$ capacity utilization of all public enterprises increased substantially, thanks to improved economic conditions and the consequent rise in demand.

The leverage variable is, as expected, negative for all enterprise groups since a high equity-asset ratio is associated with greater risk. Apart from this, the fact that public enterprises have easy access to credit has led many low-performing enterprises to depend heavily on loan capital, which imposes an undue burden on the enterprises' capital structure and adversely affects their profitability. 


\section{CONCLUSION}

To analyse the performance of public enterprises in Pakistan, four ratios were selected from a choice-set of seventeen performance indicators on the basis of their predictive power. The methodology used enabled us to select, in particular, the profitability ratios most appropriate for performance evaluation in the prevailing market conditions.

Nine poorly performing enterprises were identified whose current state was the result of the aggravation of a declining trend in profitability which was already present in the earlier years of the 1977-78 - 1981-82 period.

A comparison of the operational conditions of poorly performing enterprises with those of the well-performing ones showed that in the former, labour intensities were much higher and factor utilization was relatively unproductive. However, despite continuous deficits, the low-performing enterprises were not allowed to go into liquidation.

The regression results regarding the determinants of enterprise profitability were just as expected. Enterprise size was found to be negatively related to the profit rate while in the group of smaller enterprises the relation was positive, suggesting a certain critical level beyond which enterprise size exerts a negative influence on the profit rate.

The growth rate of the asset variable is significant and positively related to profit rate, which is explained by the increase in capacity utilization of nearly all public enterprises during the years from $1977-78$ to $1981-82$. The negative relation of leverage to the profit rate is explained by the greater risk associated with a higher equity-asset ratio. 
Table 1

Appendix I

Classification of 'Healthy' and 'Slack' Enterprises by 17 Profitability Ratios Arranged in Descending Order

\begin{tabular}{|c|c|c|c|c|c|c|c|c|c|c|c|c|c|c|c|c|}
\hline $\mathrm{PRGP}_{1}$ & $\mathrm{PRGP}_{2}$ & $\mathrm{PRGP}_{3}$ & $\mathrm{PRGP}_{4}$ & $\mathrm{PRGP}_{5}$ & $\mathrm{PRGP}_{6}$ & $\mathrm{PRGP}_{7}$ & $\mathrm{PRGP}_{8}$ & ${ }_{3} \mathrm{PRGP}_{9}$ & $\mathrm{PRGP}_{10}$ & $\mathrm{PRNW}_{1}$ & $\mathrm{PRNW}_{2}$ & $\mathrm{PRR}_{1}$ & $\mathrm{PRD}_{1}$ & $\mathrm{PRD}_{2}$ & $\mathrm{PRD}_{3}$ & $\mathrm{PRD}_{4}$ \\
\hline 95.0 & 49.4 & 23.4 & 83.7 & 43.5 & 20.7 & 50.74 & 466.05 & 55.7 & 12.5 & 688.6 & 688.6 & 23.5 & 454.8 & - & - & - \\
\hline 41.3 & 21.1 & 19.6 & 35.1 & 19.4 & 19.1 & 21.7 & 26.3 & 37.8 & 11.1 & 89.1 & 39.6 & 14.5 & 93.8 & $40.4^{s}$ & 36.8 & 9.1 \\
\hline 33.7 & 19.9 & 17.5 & 32.8 & 18.3 & 16.8 & $21.5^{\mathrm{s}}$ & 12.1 & 20.8 & 8.7 & 75.6 & 38.4 & 12.6 & 10.5 & $12.5^{\mathrm{S}}$ & 24.3 & 8.3 \\
\hline $23.6^{\mathrm{s}}$ & 18.8 & 17.3 & $18.6^{\mathrm{S}}$ & 18.0 & 14.8 & 6.1 & 8.8 & 12.5 & 5.2 & 62.5 & 29.6 & 7.8 & 1.5 & 11.2 & 23.1 & $8.0^{\mathrm{s}}$ \\
\hline 21.2 & 14.4 & 11.2 & 15.3 & 11.6 & 11.2 & 6.0 & 5.7 & 4.8 & 4.1 & 46.6 & 23.4 & 7.5 & - & $10.7^{\mathrm{s}}$ & 13.2 & 6.7 \\
\hline $18.2^{\mathrm{s}}$ & 11.2 & 10.1 & $14.6^{\mathrm{s}}$ & 11.2 & 8.2 & 5.8 & 3.1 & 2.6 & 4.0 & 35.2 & 12.8 & 4.1 & - & 6.2 & $11.6^{\mathrm{s}}$ & 6.2 \\
\hline $18.0^{\mathrm{S}}$ & 11.1 & 9.1 & 12.4 & 9.3 & 7.6 & 5.5 & $1.9^{\mathrm{s}}$ & $1.9^{\mathrm{s}}$ & $2.4^{\mathrm{s}}$ & 24.5 & 10.3 & 0.6 & - & 5.9 & 10.9 & 6.0 \\
\hline 15.4 & $7.9^{s}$ & $6.0^{s}$ & 12.1 & $6.4^{\mathrm{s}}$ & $2.9^{S}$ & $4.3^{s}$ & 1.3 & 1.5 & $1.8^{\mathrm{S}}$ & 15.8 & 6.2 & 0.5 & - & $5.0^{\mathrm{S}}$ & $10.8^{\mathrm{S}}$ & $5.7^{s}$ \\
\hline 13.9 & 4.3 & 3.9 & 11.6 & 3.1 & 2.8 & 1.6 & 1.2 & 1.1 & $1.1^{\mathrm{s}}$ & (-) $5.4^{\mathrm{s}}$ & (-) $5.4^{\mathrm{s}}$ & $-1.8^{\mathrm{s}}$ & - & $3.8^{\mathrm{S}}$ & $9.1^{s}$ & 4.6 \\
\hline 12.4 & $4.2^{\mathrm{s}}$ & $3.0^{\mathrm{s}}$ & 10.0 & $1.9^{\mathrm{S}}$ & $1.7^{\mathrm{s}}$ & 1.0 & 1.1 & $0.8^{\mathrm{s}}$ & 1.1 & (-) $38.9^{\mathrm{S}}$ & (-) $38.9^{\mathrm{s}}$ & $-2.6^{\mathrm{s}}$ & - & $3.4^{\mathrm{s}}$ & 8.7 & 4.1 \\
\hline $10.1^{\mathrm{s}}$ & $2.5^{\mathrm{s}}$ & $2.3^{\mathrm{s}}$ & $7.6^{s}$ & $1.8^{\mathrm{s}}$ & $1.4^{\mathrm{s}}$ & $-18.9^{S}$ & $-1.3^{\mathrm{S}}$ & $-1.3^{\mathrm{s}}$ & $-1.8^{\mathrm{S}}$ & $(-) 45.6^{\mathrm{s}}$ & (-) $45.6^{\mathrm{s}}$ & $-3.1^{s}$ & - & 3.0 & $8.6^{\mathrm{s}}$ & $4.0^{s}$ \\
\hline 10.0 & $2.3^{\mathrm{s}}$ & $2.1^{\mathrm{s}}$ & $6.2^{\mathrm{s}}$ & $1.6^{\mathrm{S}}$ & $1.2^{\mathrm{s}}$ & $-20.7^{\mathrm{s}}$ & $-4.8^{\mathrm{S}}$ & $-3.4^{\mathrm{s}}$ & $-4.1^{s}$ & $(-) 135.5^{\mathrm{s}}$ & $(-) 135.5^{\mathrm{s}}$ & $-7.3^{\mathrm{s}}$ & - & $2.7^{\mathrm{s}}$ & $8.1^{\mathrm{s}}$ & $3.3^{\mathrm{s}}$ \\
\hline $2.5^{\mathrm{s}}$ & $1.3^{\mathrm{S}}$ & $1.2^{\mathrm{s}}$ & $0.9^{s}$ & $0.5^{\mathrm{s}}$ & $0.4^{\mathrm{S}}$ & $-22.7^{s}$ & $-7.2^{\mathrm{s}}$ & $-6.5^{\mathrm{s}}$ & $-8.0^{\mathrm{S}}$ & $(-) 154.9^{s}$ & $(-) 154.9^{\mathrm{s}}$ & $-9.7^{s}$ & - & 2.3 & $6.4^{\mathrm{s}}$ & $3.1^{\mathrm{s}}$ \\
\hline$-6.1^{s}$ & $-0.4^{\mathrm{s}}$ & $-0.4^{\mathrm{s}}$ & $-8.7^{s}$ & $-0.6^{\mathrm{s}}$ & $-0.6^{\mathrm{S}}$ & $-28.9^{s}$ & $-26.6^{\mathrm{s}}$ & $-10.8^{\mathrm{S}}$ & $-12.5^{\mathrm{s}}$ & $(-) 173.1^{s}$ & $(-) 173.1^{s}$ & $-9.7^{s}$ & - & $1.6^{\mathrm{s}}$ & $6.2^{s}$ & $3.1^{\mathrm{s}}$ \\
\hline $31.4^{\mathrm{s}}$ & $-6.6^{\mathrm{s}}$ & $-5.8^{\mathrm{s}}$ & $-43.9^{s}$ & $-9.2^{\mathrm{s}}$ & $-8.1^{\mathrm{s}}$ & $-135.4^{\mathrm{s}}$ & $-12.1^{\mathrm{s}}$ & $-12.0^{\mathrm{s}}$ & $-12.6^{\mathrm{s}}$ & $(-) 422.1^{\mathrm{s}}$ & $(-) 422.1^{s}$ & $-9.7^{\mathrm{S}}$ & - & 0.9 & 3.4 & $0.9^{\mathrm{s}}$ \\
\hline $71.1^{\mathrm{s}}$ & $-14.0^{s}$ & $-10.6^{\mathrm{s}}-$ & $-111.5^{\mathrm{s}}$ & $-21.9^{\mathrm{s}}$ & $-16.7^{\mathrm{s}}$ & $-153.9^{\mathrm{s}}$ & $-13.7^{\mathrm{s}}$ & $-20.2^{s}$ & $-39.0^{s}$ & $(-) 571.8^{\mathrm{s}}$ & $(-) 571.4^{s}$ & $-12.3^{\mathrm{s}}$ & - & 0.3 & $0.2^{\mathrm{s}}$ & $0.1^{\mathrm{s}}$ \\
\hline
\end{tabular}

Source: Calculated from [9].

Notes: (i) $s$ denotes a low performing enterprise.

(ii) The classification error is found by expressing the number of enterprises misspecified as a percentage of the total number of enterprises in the two groups.

Appendix I

Table 2

Ranking of Public Enterprises (identified by their Code Numbers) by 'Sensitive' Profitability Ratios

\begin{tabular}{|c|c|c|c|c|c|c|c|c|c|}
\hline Rank & $\mathrm{PRGP}_{3}$ & PRGP $_{9}$ & $\mathrm{PRR}_{1}$ & $\mathrm{PRD}_{4}$ & Rank & $\mathrm{PRGP}_{3}$ & $\mathrm{PRGP}_{9}$ & $\mathrm{PRR}_{1}$ & $\mathrm{PRD}_{4}$ \\
\hline 1 & 14 & 14 & 19 & 18 & 28 & 16 & 48 & 20 & 35 \\
\hline 2 & 39 & 39 & 38 & 46 & 29 & 54 & 30 & 8 & 16 \\
\hline 3 & 3 & 13 & 42 & 38 & 30 & 23 & 46 & 53 & 52 \\
\hline 4 & 13 & 11 & 35 & 36 & 31 & 30 & 52 & 51 & 45 \\
\hline 5 & 11 & 3 & 14 & 34 & 32 & 27 & 53 & 37 & 4 \\
\hline 6 & 35 & 35 & 23 & 49 & 33 & 7 & 34 & 50 & $\underline{48}^{*}$ \\
\hline 7 & 9 & 38 & 39 & 47 & 34 & 49 & 54 & 33 & 12 \\
\hline 8 & 10 & 42 & 36 & 42 & 35 & 50 & 34 & 5 & 9 \\
\hline 9 & 15 & 10 & 46 & 15 & 36 & 47 & 49 & 29 & 3 \\
\hline 10 & 4 & 44 & 48 & 32 & 37 & 19 & 43 & 4 & 7 \\
\hline 11 & 34 & 9 & 47 & 8 & 38 & 31 & 50 & 27 & 24 \\
\hline 12 & 44 & 4 & 49 & 20 & 39 & $\underline{45^{*}}$ & 47 & 2 & 37 \\
\hline 13 & 38 & 23 & 45 & 23 & 40 & 2 & 26 & 18 & 29 \\
\hline 14 & 6 & 15 & 30 & 53 & 41 & 52 & 37 & $\underline{15}^{*}$ & 44 \\
\hline 15 & 28 & 6 & 11 & 40 & 42 & 53 & 19 & 1 & 30 \\
\hline 16 & 29 & 20 & 32 & 51 & 43 & 22 & 51 & 10 & 26 \\
\hline
\end{tabular}


List of Profitability Ratios and their Codes

I. Ratios based on Gross Profit

PRGP $_{1} \quad$ : Gross Profit/Sales (Net of Excise)

$\mathrm{PRGP}_{2}$. Gross Profit/Total Assets

PRGP $_{3}$ : Gross Profit/Total Assets \& Accumulated Depreciation

PRGP $_{4} \quad$ : $\quad$ Gross Profit less Depreciation/Sales (Net of Excise)

PRGP $_{5} \quad$ : Gross Profit less Depreciation/Total Assets

PRGP $_{6}$ : Gross Profit less Depreciation/Total Assets \& Depreciation

$\mathrm{PRGP}_{7} \quad$ : Gross Profit less Financial Charges and Taxation/Sales (Net of Excise)

PRGP $_{8}$ - Gross Profit less Financial Charges and Taxation/Total

$$
\text { Assets }
$$

PRGP, : Gross Profit less Financial Charges and Taxation/Total Assets \& Accumulated Depreciation

PRGP $_{10}$ : Gross Profit less Financial Charges and Taxation/Current Liabilities

\section{Ratios based on Net Worth}

PRNW $_{1}$ : Net Profit before Taxation/Net Worth

$\mathrm{PRNW}_{2}$ : Net Profit less Taxation/Net Worth

\section{Retention Ratios}

PRR $_{1}$ : Retained Profit \& Depreciation Provision/Debt

\section{Distribution Ratios}

$\mathrm{PRD}_{1}$. Total Dividend/Net Profit after tax

$\mathrm{PRD}_{2} \quad$ : Depreciation/Sales (net of Excise)

$\mathrm{PRD}_{3} \quad$ : Depreciation/Net Fixed Assets

$\mathrm{PRD}_{4}$ : Depreciation/Gross Fixed Assets 
List of Enterprises and their Codes

\begin{tabular}{|c|c|}
\hline $\begin{array}{c}\text { Enterprise } \\
\text { Code }\end{array}$ & Enterprise \\
\hline 1. & Heavy Foundry and Forge \\
\hline 2. & Heavy Mechanical Complex Limited \\
\hline 3. & Karachi Pipe Mills Limited \\
\hline 4. & Metropolitan Steel Corporation Limited \\
\hline 5. & Northern Foundry and Engineering Works Limited \\
\hline 6. & Pakistan Engineering Company \\
\hline 7. & Pakistan Machine Tool Factory Limited \\
\hline 8. & Pakistan Switchgear Limited \\
\hline 9. & Pioneer Steel Mills Limited \\
\hline 10. & Quality Steel Works Limited \\
\hline 11. & Awami Autos Limited \\
\hline 12. & Bela Engineers Limited \\
\hline 13. & Domestic Appliances Limited \\
\hline 14. & Mack Trucks of Pakistan Limited \\
\hline 15. & Millat Tractors Limited \\
\hline 16. & National Motors Limited \\
\hline 17. & Naya Daur Motors Limited \\
\hline 18. & Pakistan Tractors \\
\hline 19. & Republic Motors Limited \\
\hline 20. & Sind Engineering \\
\hline 21. & Trailer Development Corporation Limited \\
\hline 22. & Antibiotics (Pakistan) Limited \\
\hline 23. & Ittehad Chemicals \\
\hline 24. & Ittehad Pesticides \\
\hline 25. & Kurram Chemicals Company Limited \\
\hline 26. & Nowshera DDT Factory \\
\hline 27. & Pakdyes and Chemicals Limited \\
\hline 28. & Pakistan PVC Limited \\
\hline 29. & Ravi Engineering Limited \\
\hline 30. & Ravi Rayon Limited \\
\hline 31. & Sind Alkalis Limited \\
\hline 32. & Swat Ceramics Company Limited \\
\hline 33. & Swat Elutriation Plant \\
\hline 34. & Lyallpur Chemicals and Fertilizers Limited \\
\hline
\end{tabular}

35. Pak American Fertilizers Limited

36. Pak Arab Fertilizers Limited

37. Pak China Fertilizers Limited

38. Pak Saudi Fertilizers Limited

39. Bannu Sugar Mills Limited

40. General Refractories Limited

41. Harnai Woollen Mills Limited

42. Indus Steel Pipe

43. Larkana Sugar Mills Limited

44. Quaidabad Woollen Mills Limited

45. Associated Cement Wah

46. Gharibwal Cement Limited

47. Javedan Cement Limited

48. Maple Leaf Cement Limited

49. Mustekham Cement Limited

50. National Cement Limited

51. White Cement Limited

52. Zeal Pak Cement Limited

53. National Refinery Limited

54. National Petrocarbon Limited 


\section{REFERENCES}

1. Ahmed, Z. U. "Financial Profitability and Losses in Public Enterprises". Public Enterprise. Vol. 2, No. 1, 1981.

2. Gillis, M. "Efficiency in State Enterprises: Selected Cases in Mining from Asia and Latin America". Cambridge, Mass.: Harvard Institute for International Development, Harvard University. 1977. (Development Discussion Paper No. 27)

3. Gupta, L. C. Financial Ratios for Monitoring Corporate Sickness. Delhi: Oxford University Press. 1983.

4. Jenkins, G. P. "An Operational Approach to the Performance of Public Sector Enterprises". Cambridge, Mass.: Harvard Institute for International Development, Harvard University. 1978. (Development Discussion Paper No. 47)

5. Jenkins, G. P. Performance Evaluation and Public Sector Enterprises. Cambridge, Mass.: Harvard Institute for International Development, Harvard University. 1978. (Development Discussion Paper No. 46)

6. Jones, L. P. "Efficiency of Public Manufacturing Enterprises in Pakistan". Unpublished report prepared for World Bank and the Ministry of Production, Govt. of Pakistan. 1981.

7. Lindsey, W. C. "Firm Size and Profit Rate in Philippine Manufacturing". Journal of Developing Areas. Vol. 15, No. 3. April 1981.

8. Mohsin, M. Financial Planning and Control. New Delhi: Vikas. 1980.

9. Pakistan. Ministry of Production. Experts Advisory Cell. Public Sector Industries. Annual Report 1981-82. Volumes I and II. Islamabad. 1983.

10. Walker, E. W., and W. H. Baughn. Financial Planning and Policy. New York: Harper and Row. 1964. 


\section{Comments on}

\section{"The Profitability of Public Enterprises in Pakistan"}

This paper on the evaluation of public enterprises breaks fresh ground. Profitability ratios have been used extensively in the West, but have hardly been touched in the underdeveloped countries (UDCs). I shall point out later that the extension of this analysis to the UDCs is a non-trivial exercise. The only attempt in this direction was a very limited one by Gupta [2]. I should like, here, to discuss the problems of extension just mentioned, the methodology used in the paper, the insights it provides and the possible extensions of this work.

A fundamental problem for economists of the UDCs is that the methods developed in the West rely on assumptions that are largely invalid in a UDC. In particular, the statistical methods so essential for quantitative economic analysis in the West can not always be relied on in smaller economies. New methods need to be developed which are not elaborations of the highly sophisticated techniques recently developed but simple approaches that take a fresh look at the old economic problems in an entirely new context. It is better to rely on an intuitive understanding of economic problems rather than on highly sophisticated procedures of doubtful applicability in situations where the basic questions to be dealt with are not clear. Simplicity, rather than sophistication, is required. It is in this context that I regard this paper as an important step in the development of basic economic analytic tools for the UDCs.

It is generally believed that only in developed countries can public enterprises be profitable and in the UDCs the only purpose of public enterprises is to achieve extra-economic benefits. The point brought out by the analysis of Khwaja Sarmad is that we need not resign ourselves to accepting economic losses to obtain extraeconomic benefits. If we can identify the causes of the bad performance of public enterprises, we may be able to provide the inputs required to make them profitable. To be able to do so we should be able to assess which enterprises need help, i.e. we need to formulate criteria to assess the performance of public enterprises. It should be borne in mind that we can not assume that the criteria developed in the West will be equally applicable in such entirely different conditions. 
The most obvious way to develop the required criteria is to take some definitely healthy enterprises and some definitely unhealthy enterprises and see which profitability ratios give what are known, a priori, to be the correct answers. Having validated some ratios and invalidated others on an empirical basis, we can use the validated ratios in the given UDC. They obviously do satisfy the assumptions underlying the use of those ratios. This is precisely what has been done in this paper.

Of course, it is not quite so simple. Every ratio will have some likelihood of misclassification, i.e. classifying a known healthy enterprise as unhealthy or vice versa. It is not to be expected that there will be any ratio which would not yield a minor misclassification. Now, if an enterprise is weak in some aspects, we would expect that to show up in some ratio and not in others. If an enterprise is weak in many aspects, we would expect that weakness to show up in many ratios. On the other hand, a ratio is to be accepted as a reasonably good measure only if it gives very few misclassifications. Following this procedure, four ratios were selected as the ones giving the least misclassification and measuring different aspects of the health of the enterprise. At present only the first step in this direction is being taken. As such, only the most crude assessment can be made. No attempt has been made to measure the degree of misclassification, or to incorporate the weightage of the various enterprises in obtaining average values of any quantities. At the next step, of course, these points would need to be studied. In fact the importance of the weights to be attached is already clear in Table 7 of the paper. Whereas the gross profit of all enterprises aggregated is positive, as is the value added per employee, the ratio presented is negative. This is due to equal weights having been assigned to healthy and slack enterprises. Obviously, however, the bulk of the wealth is in the healthy rather than in the slack enterprises. The equal weightage leads to the paradoxical result. By such a study, one may attempt to provide an average index of the health of an enterprise, taking a weighted average of the four ratios according to the extent to which they misclassify.

The procedure adopted from here was to classify those enterprises which came out to be slack according to all the four ratios as definitely unhealthy and those that came out according to all the four ratios as definitely healthy. The problem arises for those enterprises which do not fall into either of these categories. Those that are assessed as unhealthy according to only one ratio may be regarded as healthy, as it is quite likely that the effect is due to a classification error. On the other hand, if an enterprise is assessed as unhealthy according to three ratios, it would be highly unlikely that it was a misclassification, the probability in this case being the cube of the probability in the former case. On the borderline remains the case of those enterprises which are assessed unhealthy according to two ratios. The above-mentioned measure of the degree of misclassification and the weights to be attached to each ratio would, presumably, better define how to treat these borderline cases.
I have already pointed out two directions in which further work needs to be done. Another direction is concerned with an insight provided by the analysis in the paper. On looking at the first three ratios for gross profits it was noticed that the third was the best in that it not only minimized misclassification but also made the most sense in economic terms. The reason for this was that it allowed for inflation since depreciation accounts for the change in price levels. With hindsight, it is quite clear that in a high-inflation situation, the third ratio must be preferred. Here the structure of inflation in the economy has not been taken into account. Recent work [1] shows that there are fresh insights to be gained by taking a dual-sector model of inflation in Pakistan. It would be relevant to consider whether the inflation structure noted there is not reflected in this analysis of the profitability of enterprises. The amount of inflation to be incorporated and the way it is to be dealt with will be affected by its dual nature. It is not clear as yet how this discounting should be done, but it is quite apparent that there is a wealth of information waiting to be uncovered here.

To sum up, this paper is an important first step towards developing techniques for assessing the health of public enterprises. Given a marginally unhealthy enter prise, these techniques should provide some insight into the remedies to be recommended for these enterprises. A comparative study of the ratios for different UDCs should provide a deeper understanding of how the structure of the economy as a whole affects the health of public enterprises. It should be emphasized that this is only a first step. There is much room for improvement in the methods used in terms of both the statistical tools and the calculation procedure used for discounting etc These further steps would, however, only refine the basic insights provided here.

Associate Professor,

Mathematics Department,

Quaid-i-Azam University,

Islamabad

Asghar Qadir

\section{REFERENCES}

1. Afridi, Usman, and Asghar Qadir. "Dual Sector Inflation in Pakistan". Pakistan Development Review. XXII, No. 3. Autumn 1983.

2. Gupta, L.C. Financial Ratios for Monitoring Corporate Sickness. Delhi. 1983. 